Artigo de Revisão

\title{
The role of the Major Histocompatibility Complex in the Immunobiology of Self-Aromas
}

\section{O papel do Principal Complexo de Histocompatibilidade (MHC) na imunobiologia dos aromas}

Mariana Cavalheiro Magri ${ }^{1}$, Adele Caterino-de-Araujo²

\section{RESUMO}

Os autores apresentam uma revisão sobre os mecanismos imunobiológicos no processo da olfação, reunindo informações atuais e relevantes sobre os odores liberados pelo organismo de vertebrados e sua associação com o sistema imune. Algumas teorias sobre características estruturais de odores ou aromas têm sido propostas, sendo as mais importantes: a teoria estereoquímica e da vibração do odor. Diversas técnicas baseadas nas atividades cerebrais associadas a processos sensoriais, têm sido particularmente importantes na avaliação dos efeitos fisiológicos dos odores. Moléculas do Principal Complexo de Histocompatibilidade (MHC) foram identificadas nos odores próprios (odortipos), e componentes voláteis do $\mathrm{MCH}$, detectados na urina de camundongos. Os estudos mais importantes que relacionam os receptores olfatórios com o MHC foram obtidos em modelo experimental murino. Esses estudos demonstram que os odores próprios desempenham um importante papel na escolha do companheiro(a), e na relação entre mãe e prole. Um sistema de sensor de gases chamado "nariz eletrônico" foi usado como instrumento capaz de detectar moléculas do MHC nos odortipos. Concluindo, a diversidade de odores próprios ou odortipos parece ser conseqüência do elevado polimorfismo do MHC, que é próprio de cada indivíduo. Apesar das controvérsias entre cientistas em relação a imunobiologia dos aromas principalmente em seres humanos, pode-se supor que odores próprios influenciam a escolha de parceiros em humanos. Mais estudos são necessários para esclarecer e confirmar esta hipótese.

\section{Unitermos: MHC, Odores, Olfato.}

Citation: Magri MC, Caterino-de-Araujo A. O papel do Principal Complexo de Histocompatibilidade (MHC) na imunobiologia dos aromas. Rev Neurociencias 2005; 13(4):196-200.

\section{SUMMARY}

The authors present a review of the immunobiological mechanism of olfaction considering current and relevant information about the odors released by vertebrate organisms, and its association with the immune system. Many theories concerning to the type and the quality of the molecular structures of odors or aromas have been proposed, but the most important are the steric theory of odor and the vibration theory of odor. Several techniques based on brain activities have been studied in association with sensorial processes, and they were particularly important to

Institutuion: Immunology Department of Instituto Adolfo Lutz

1 - BSc, Fellowship of Fundação de Amparo à Pesquisa de São Paulo (FUNDAP), Immunology Department of Instituto Adolfo Lutz, São Paulo, SP, Brasil

2 - BsC, PhD, Scientific Researcher of the Immunology Department of Instituto Adolfo Lutz, São Paulo, SP, Brasil

Address for correspondence: Adele Caterino-de-Araujo

Immunology Department of Instituto Adolfo Lutz

CEP 01246-902, São Paulo, SP, Brasil

Phone/Fax: +55-21-3068-2898

E-mail: caterino@ial.sp.gov.br

Trabalho recebido em 30/08/05. Aprovado em 07/11/05

* This manuscript is part of the Graduation Monograph of M.C. Magri presented to Pontifícia Universidade Católica de Campinas, SP., in 2003. At present, M.C.Magri is a fellowship of FUNDAP at Instituto Adolfo Lutz under supervision of A. Caterino-de-Araujo. 
evaluate the physiologycal effects of odors. Molecules of the Major Histocompatibility Complex (MHC) have been identified in individual body odors (odortype), and volatile compounds of the $\mathrm{MHC}$ were easily detected in the urine of mice. The major relevant studies related to the Olfactory Receptors (ORs) and the MHC were conducted in mice models, and these studies demonstrated that the odortype has an important role in the partner choice, as well as in the relationship between mothers and their offsprings. A sensorial gas apparatus called "eletronic nose" has been used as an instrument capable of detecting molecules of the MHC in the odortypes. In conclusion, the diversity of self-aromas or odortypes seems to be generated in the context of the $\mathrm{MHC}$, and consequently varies according to the genetic background of the individual. In spite of several controversies among scientists concerning to the immunobiology of the aromas, mostly in human beings, we could hypothesize that similar types of odors could influence the human choice. Future studies are necessary to clarify and confirm these findings in human beings.

\section{Keywords: MHC, Odors, Smell.}

Citation: Magri MC, Caterino-de-Araujo A. The role of the Major Histocompatibility Complex in the Immunobiology of SelfAromas. Rev Neurociencias 2005; 13(4):196-200.

\section{AROMA}

Aroma is a Greek word that means fragrance, but is also called odor. Odors are perceived by the Olfactory System ${ }^{1}$, and many theories relating to the type and quality of the molecular structures of the odors have been proposed. The most important are the steric theory of odor and the vibration theory of odor ${ }^{2,3}$.

During the fifties, an English scientist named John Amoore proposed the steric theory of odor. He speculated that the nose receptors responsible for sending each aroma signal to the brain, work as a system of the type "key-lock". The combination of the odor molecules of different structural forms (keys) with their specific receptors (locks) generate signals, which in turn are sent to the brain, and culminate with the perception of different aromas ${ }^{2,3}$.

The vibration theory of odor initially proposed by Dyson, and later on by Wright, defends that such recognition and the similarities among the molecules of the aromas are related to their intramolecular vibration, rather than to their molecular shapes ${ }^{2,3}$. Keller \& Vosshall using psychophysical methods in humans to test the vibration theory showed no evidence to support this theory, so the steric theory is the most accepted at present ${ }^{4}$.

In order to appreciate the physiologycal effects of odors, several techniques based on the brain activity associated to sensorial information processes have been evaluated 5 .

\section{Olfactory System}

The odors are volatile chemical compounds carried to the Olfactory Region by the inhalation of the air $2,6-8$. When the aromas are inhaled, their particles go to the olfactory membrane, which possess Olfactory Receptors (ORs) composed by bipolar nervous cells derived from the Central Nervous System (CNS) $)^{6,7,9}$. The odor in contact with the olfactory surface spreads out in the mucus, opening the cilia. Then, each molecule of odor binds to a protein receptor present in the cilia membrane, and finally, the olfactory nerve transmits a signal to the CNS as an action potential ${ }^{6,9}$.

The olfactory signals are transmitted to the Olfactory Bulb that spreads out the distribution of the neural receptors odor innervation on the Nasal Epithelium, and supplies projections of the axons to the Olfactory Cortex, also called Skull Nerve I. The brain receives the axons and releases neurochemical substances $6,7,9,10$.

In addition, there are glomeruli inside the Bulb. The glomeruli are discrete neuropil structures formed by the incoming axons of a subset of olfactory receptor neurons expressing the same olfactory receptor and by the dendrites of the mitral cells making synaptic connections with these incoming axons $\mathbf{6}^{6,7,9,10}$. Recent researches suggest that different glomeruli respond to different odors, so, it is possible that the glomeruli are the best way for the analysis of different signals transmitted to the CNS from the odors ${ }^{6}$.

Several studies have demonstrated that some species of vertebrates possess the Vomeronasal Organ (VNO), which is a peripheral sensorial organ, accessory to the Olfactory System. The function of the VNO seems to be exclusively the detection of chemical signals, which could be related to sexual behavior and mark of territory ${ }^{11}$.

It is not known if there is some place for human communication through the odors and the pheromones. In adult human beings, the VNO does not exist, but the pheromonal actions are likely mediated by the main OIfactory Epithelium. One of the evidence of this chemical communication among humans is the notable example of a synchronization tendency of the menstrual cycles in women who live together ${ }^{11}$

\section{Olfactory Code}

The ORs are encoded by a large family of genes that including approximately 900 genes in humans and 1,500 in mice. The polymorphism in the sequences of the $O R$ genes have already been described, and shows the oc- 
currence of individual differences in the odors detection. Each neuron of the Olfactory Epithelium expresses only one allele of $O R$ gene $^{12}$. In addition, $70 \%$ of the human $O R$ genes had become not functional pseudogenes ${ }^{13}$.

The studies of the diversity, polymorphism and evolution of the $O R$ genes, will provide a better comprehension of the biology of the olfactory process ${ }^{12,14}$, important to understand the specific bind of the odors to their receptors, including the $\mathrm{MHC}^{8}$.

\section{Major Histocompatibility Complex}

The Major Histocompatibility Complex (MHC) belongs to a group of surface molecules encoded by a family of approximately 50 genes. The great diversity of these genes suggests that their mechanisms have had an enormous evolutionary evolvement ${ }^{15}$.

The MHC is responsible for the molecular recognition of antigens presented in the cells surface, and acts always in addition to CD4 and CD8 molecules. The $\mathrm{MHC}$ has also a biological function of restriction of the self/nonself system ${ }^{16,17}$.

\section{Odortype}

Individuals of different species, including human beings, have individual body odors (odortypes), and by the Olfactory System it is possible to distinguish one individual from another ${ }^{(15,18-21)}$. The odortype transmits important information concerning to the identity, the reproductive status, and the health of the individual. It also promotes recognition between generations ${ }^{20,22}$.

Even though the human $\mathrm{MHC}$ is more difficult to detect compared to the mice $\mathrm{MHC}^{23-26}$, a preference for odortypes has also been demonstrated in humans, mainly in the context of Class I molecules ${ }^{24}$. The knowledge of the human odortype expressed in urine is still restricted ${ }^{19}$.

It is known that the combinatorial potential of the $\mathrm{MHC}$ genes is quite vast, therefore, a small change of one nucleotide can modify the odortype ${ }^{15}$.

\section{Neural Activation of the Olfactory Bulb}

Odortypes from mice differing in the MHC elicit distinct, but overlapping spatial activity map in the glomerular layer of the Olfactory Bulb. This shows that the spatial activity map in the Olfactory Bulb carries enough information to allow the mice to discriminate MHC odortypes.

In order to understand the neural activation of the Olfactory Bulb, mice are killed soon after odortype exposition, and the sensor stimulation of Olfactory Bulb are explored ${ }^{20}$. The space standards obtained of the odortype activity are used as a fingerprint of each mice
MHC. This kind of approach permits to describe the odortypes ${ }^{20,21}$.

\section{Partner Choice in Mice}

The ORs first studies were performed in mice in 1991 by Buck and Axel, and until now, the major studies that correlate the ORs with the $\mathrm{MHC}$ have been carried in murine models ${ }^{2}$. Of note, Linda Buck and Richard Axel were awarded with the 2004 Nobel Prize in Physiology or Medicine, because of their inestimable contribution on the study of aromas. They discovered in 1991, a large gene family that give rise to an equivalent number of Olfactory Receptor types ${ }^{27}$.

According to gender, some researches demonstrated that males exclude females who have identical MHC. These data stand that the identification among mice occurs by the odortype detection, and has a profound effect in social interactions. These observations distressed immunobiologists and neurobiologists in a recent past, but nowadays they show great progress in relation to the study and understanding of this effect ${ }^{20,21}$.

\section{Involvement of the MHC since the Birth}

Female mice have the ability and the tendency to recognize their offspring through the MHC. In a few days the newly born mice are able to recognize their mothers by the odortype ${ }^{15,20,21}$. This type of study has demonstrated that the $\mathrm{MHC}$ is the mainly determinant of the relationship between the mother and the newly born mice, followed by secondary factors ${ }^{15}$.

One study carried with women after the birth of their babies showed that whether mother's urine were mixed with urine from their own baby and from other baby, a trained mouse was capable to recognize the sample which present urines of the same genomic origin, which means, recognition of the similar odortypes ${ }^{28}$.

\section{Partner Choice in Humans}

Different from mice, a few numbers of studies have been conducted in humans. In one of them, 49 women and 44 men were identified in relation to their own MHC. The men had worn at-shirt for two nights. On the following day, the women had been asked to judge the most pleasant t-shirts odors. Interestingly, they chose the t-shirts that had been worn by the men with the MHC genotype different from their own genotype. In contrast, when the women had to decide on the least pleasant odor, they chose the t-shirts used by men with the MHC genotype more similar to theirs (similar odortypes) ${ }^{29}$. Curiously, women who were in the fertile period of the menstrual cycle did not show clear preference ${ }^{29}$. A very similar study showed that men also prefer t-shirts worn by women whose odortype is different from theirs ${ }^{29}$. 
Some hypotheses have been proposed to explain the $\mathrm{MHC}$ involvement in partner choice ${ }^{28}$. These hypotheses emphasize the $\mathrm{MHC}$ miscellaneous in the population and consequently the enhancement of the resistance against infectious diseases and parasitic diseases, and prevention of blood relative marriages ${ }^{28}$.

\section{"Eletronic Nose"}

"Eletronic nose" ("e-nose") is an apparatus of a sensorial gas that detects particles of the MHC in odors. The "e-nose" consists of a set of chemistry-physicists detectors, made of microscales of quartz crystal and oxidated metal to semiconduction. This sensor changes the frequency and the conduction of some molecules present in the gas. The changes are characterized by particular odors ${ }^{26}$.

An experiment with the "e-nose" performed in a total of 153 urine samples from six females and six male mice, indicated that the $\mathrm{MHC}$ molecules are detectable by the "e-nose" as the major urine odor component. In addition, the "e-nose" showed differences in urine compounds among the same male species; the Class II MHC are not detected in several cases, while the Class I MHC products are always detected ${ }^{26}$. These findings proved that the $\mathrm{MHC}$ is directly related to the odortype $\mathrm{e}^{15,20,22,26}$.

Odor compounds present in serum of mice are also clearly distinguished by the "e-nose" apparatus ${ }^{26}$. It is believed that the human sweat contains the MHC odor. Through the "e-nose" it was possible to distinguish primary and secondary components in human odortype, which indicates $\mathrm{MHC}$ influences ${ }^{26}$.

\section{REFERENCES}

1. Kirschmann GJ, Kirschmann JD. Nutrition Almanac. $4^{\text {th }}$ ed. New York: McGraw-Hill; 1996.

2. Leffingwell and Associates. Olfaction - A Review. [http:// www.leffingwell.com/reviews.htm]. Accessed March 27, 2003.

3. Tenius BSM, Schroeder EK, Schenato RA. Ambergris: Perfume e Síntese. Revista Química Nova 2000; 23 (2): 225-230.

4. Keller A, Vosshall LB. A psychophysical test of the vibration theory of olfaction. Nature Neuroscience 2004; 7(4): 337-338.

5. Masago R, Matsuda T, Kikuchi Y, Miyazaki Y, Iwanaga K, Harada $\mathrm{H}$, Katsuura T. Effects of Inhalation of Essential Oils on EEG Activity and Sensory Evaluation. Journal of Physiological Anthropology and Applied Human Science 2000; 19(1): 35-42. [http://www.jstage.jst.go.jp/browse/]

\section{Odortype and the Diagnosis of Diseases}

It is well known that genetic changes as well as metabolic changes, modify the human body odors, and some human diseases can be diagnosed by the odortype. Recently, it was observed in mice presenting the virus responsible for the Mouse Mammary Tumor Virus (MMTV), that their odor changed in males and females, regardless the presence or the absence of the tumor. This finding stimulated studies of odortype in humans infected with virus that causes diseases, and stands the possibility of treating with success these infected patients, before developing a tumor ${ }^{30}$.

\section{CONCLUSIONS}

The studies presented in this review show the importance of the odortype in the social relationship, mostly in animal models. Indeed, confirm the presence of the volative compounds of the MHC in urine of mice. Studies in human beings are rare, but the data collected until now induce doubts and curiosities, and stimulate new studies concerning the real influence of the odortype in human choice.

\section{ACKNOWLEDGMENTS}

We are grateful to Prof. Dra. Irandaia Ubirajara Garcia by supporting the development of this work in Campinas.
6. Guyton AC, Hall JE. Fisiologia Humana e Mecanismos das Doenças. $6^{\text {th }}$ ed. Rio de Janeiro: Guanabara Koogan; 1998.

7. Ganong WF. Fisiologia Médica. $17^{\text {th }}$ ed. Rio de Janeiro: Guanabara Koogan; 1999.

8. Zozulya S, Echeverri F, Nguyen T. The Human Olfactory Receptor Repertoire. Genome Biology 2001; 2 (6): 18.118.12.

9. Junqueira IC, Carneiro J. Histologia Básica. $9^{\text {th }}$ ed. Rio de Janeiro: Guanabara Koogan; 1999. 427p.

10. Guthrie KM, Anderson AJ, Leon M, Gall C. Odor-Induced Increases in c-fos mRNA Expression Reveal an Anatomical "Unit" for Odor Processing in Olfactory Bulb. Proc Nat Acad Sci USA 1999; 90 (8): 3329-3333.

11. Meredith M. Humam Vomeronasal Organ Function: A Critical Review of Best and Worst Cases. Chemical Senses 2001; 21: 433-445. [http://chemse.oupjournals.org/] 
12. Meredith M. Vomeronasal Function. Chemical Senses 1998; 23: 463-466.

13. Rouquier S, Blancher A, Giorgi D. The Olfactory Receptor Gene Repertoire in Primates and Mouse: Evidence for Reduction of the Functional Fraction in Primates. Proc Nat Acad Sci USA 2000; 97 (6): 2870-2874.

14. Glusman G, Yanai I, Rubin I, Lancet D. The Complete Human Olfactory Subgenome. Genome Research 2001; 11 (5): 685-702. [http://www.genome.org]

15. Yamazaki K, Beauchamp GK, Curran M, Bard J, Boyse EA. Parent-Progeny Recognition as function of $\mathrm{MHC}$ Odortype Identity. Proc Nat Acad Sci USA 2000; 97(19): 10500-10502.

16. Abbas AK, Lichtman AH, Pober JS. Imunologia Celular e Molecular. $4^{\text {th }}$ ed. Rio de Janeiro: Revinter; 2003.

17. Roitt I, Brostoff J, Male D. Imunologia. $4^{\text {th }}$ ed. São Paulo: Manole; 1997.

18. Beauchamp GK, Katahira K, Yamazaki K, Mennella JA, Bard J, Boyse EA. Evidence Suggesting that the Odortypes of Pregnant Women are a Compound of Maternal and Fetal Odortypes. Proc Nat Acad Sci USA 1995; 92 (7): 2617-2621.

19. Yamazaki K, Beauchamp GK, Singer A, Bard J, Boyse EA. Odortypes: Their Origin and Composition. Proc Nat Acad Sci USA 1999; 96 (4): 1522-1525.

20. Schaefer ML, Young DA, Restrepo D. Olfactory Fingerprints for Major Histocompatibility Complex-Determined Boby Odors. J Neurosc 2001; 21 (7): 2481-2487.

21. Wedekind C, Penn D. MHC Genes, Body Odours, e Odours Preferences. Nephrology Dialysis Transplantation 2000; 15: 1269-1271. [http://ndt.oupjournals.org/]

22. Schaefer ML, Yamazaki K, Osada K, Restrepo D, Beauchamp GK. Olfactory Fingerprints for Major Histocompatibility Complex-Determined Body Odors II: Relationship
Among Odor Maps, Genetics, Odor Composition, and Behavior. J Neurosc 2002; 22 (21): 9513-9521.

23. Yamazaki K, Beauchamp GK, Imai Y, Bard J, Phelan SP, Thomas L, Boyse EA. Odortypes Determined by the Major Histocompatibility Complex in Germfree Mice. Proc Nat Acad Sci USA 1990; 87 (21): 8413-8416.

24. Yamazaki K, Beauchamp GK, Shen FW, Bard J, Boyse EA. Discrimination of Odortypes Determined by the Major Histocompatibility Complex Among Outbred Mice. Proc Nat Acad Sci USA 1994; 91 (9): 3735-3738.

25. Ehlers A, Beck S, Forbes SA, Trowsdale J, Volz A, Younger R, Ziegler A. MHC-Linked Olfactory Receptor Loci Exhibit Polymorphism and Contribute to Extended HLA/OR-Haplotypes. Genome Research 2000; 10 (12): 1968-1978.

26. Montag S, Frank M, Ulmer H, Wernet D, Gopel W, Rammensee HG. "Eletronic nose" Detects Major Histocompatibility Complex-Dependent Prerenal and Postrenal Odor Components. Proc Nat Acad Sci USA 2001; 98 (16): 9249-9254.

27. Howard Hughes Medical Institute. Richard Axel and Linda Buck Awarded 2004 Nobel Prize in Physiology or Medicine. [http://www.hhmi.org/news/2004nobel.html]. Accessed October 04, 2004.

28. Young JM, Trask BJ. The Sense of Smell: Genomics of Vertebrate Odorant Receptors. Human Molecular Genetics 2002; 11 (10): 1153-1160. [http://hmg.oupjournals.org/]

29. Thornhill R, Gangestad SW, Miller R, Scheyd G, McCollough JK, Franklin M. Major Histocompatibility Complex Genes, Symmetry, and Body Scent Atractiveness in Men and Woman. Behavioral Ecology 2003; 14 (5): 668-678. [http://beheco.oupjournals.org/]

30. Yamazaki K, Boyse EA, Bard J, Curran M, Kim D, Ross SR, Beauchamp GK. Presence of Mouse Mammary Tumor Virus Specifically Alters the Body Odor of Mice. Proc Nat Acad Sci USA 2002; 99 (8): 5612-5615. 